\title{
Reference diffraction patterns, microstructure, and pore-size distribution for the copper (II) benzene-1,3,5-tricarboxylate metal organic framework (Cu-BTC) compounds - CORRIGENDUM
}

W. Wong-Ng, J. A. Kaduk, D. L. Siderius, A. L. Allen, L. Espinal, B. M. Boyerinas, I. Levin, M. R. Suchomel, J. Ilavsky, L. Li, I. Williamson, E. Cockayne, and H. Wu

doi:10.1017/S0885715614001195, Published by Cambridge University Press, 17 December 2014.

In Wong-Ng et al. ${ }^{1}$, the author D. L. Siderius should appear as D. W. Siderius.
Wong-Ng, W, Kaduk, J. A., Siderius, D. L., Allen, A. L., Espinal, L., Boyerinas, B. M., Levin, I., Suchomel, M. R., Ilavsky, J., Li, L., Williamson, I., Cockayne, E., and Wu, H. (2015). "Reference diffraction patterns, microstructure, and pore-size distribution for the copper (II) benzene-1,3,5-tricarboxylate metal organic framework (Cu-BTC) compounds," Powder Diffraction 30(1), 2-13.

The authors regret the error. 